\title{
Terrestrial Foraging by Cacajao melanocephalus ouakary (Primates) in Amazonian Brazil: Is Choice of Seed Patch Size and Position Related to Predation Risk?
}

\author{
Adrian A. Barnett ${ }^{a, c}$ Thais Almeida ${ }^{b}$ Wilson R. Spironello ${ }^{c}$ \\ Welma Sousa Silvad Ann MacLarnon ${ }^{a}$ Caroline Ross ${ }^{a}$ \\ ${ }^{a}$ Centre for Research in Evolutionary and Environmental Anthropology, Roehampton \\ University, London, UK; 'baboratório de Herpetologia, Universidade Federal do Mato \\ Grosso, Boa Esperança, 'Coordenação de Biodiversidade, Instituto Nacional de Pesquisas da \\ Amazônia, Manaus, and Instituto de Ciências Exatas e Tecnologia, Universidade Federal do \\ Amazonas, Itacoatiara, Brazil
}

\section{Key Words}

Diet $\cdot$ Eschweilera $\cdot$ Igapó $\cdot$ Predation-sensitive foraging $\cdot$ Pithecidae $\cdot$ Seedling

\begin{abstract}
We analyse the behaviour of Cacajao melanocephalus ouakary feeding at patches of germinating seedlings in dried-out flooded forest. Seedlings of Eschweilera tenuifolia (Lecythidaceae) were the most commonly eaten (88.9\%). Some seed patches were revisited over several days, while others were consistently ignored. We tested 3 predictions relating uacari terrestrial foraging behaviour to: (1) arboreal escape route proximity, (2) seed patch size choice and (3) temporal patterns of repeat exploitation. Comparison of fed-at and ignored patches revealed significant preferences for larger patches, and for those close to arboreal refuges but distant from dense ground-based vegetation. Support for these predictions is interpreted as evidence for predation risksensitive foraging.

Copyright $\odot 2012$ S. Karger AG, Basel
\end{abstract}

\section{Introduction}

While terrestrial activity in predominantly arboreal species appears quite common in Paleotropical primates (e.g. Cercopithecus mitis [Smith et al., 2008]; Procolobus kirkii [Nowak and Lee, 2011]), it is rarer, though not unknown, in the larger frugivorous Neotropical taxa (Ateles [Campbell et al., 2005]; Brachyteles [Tabacow et al., 2009]). However, it appears to be very infrequent in pitheciines, the clade of Neo-

\begin{tabular}{ll}
\hline KARGER & (c) 2012 S. Karger AG, Basel \\
0015-5713/12/0832-0126\$38.00/0 \\
$\begin{array}{l}\text { Fax +41 61306 1234 } \\
\begin{array}{l}\text { E-Mail karger@karger.ch } \\
\text { www.karger.com }\end{array}\end{array}$ & $\begin{array}{l}\text { Accessible online at: } \\
\text { www.karger.com } / \mathrm{fpr}\end{array}$
\end{tabular}

Adrian A. Barnett

Centre for Research in Evolutionary and

Environmental Anthropology, Roehampton University London SW15 4JD (UK)

E-Mail adrian.barnett1.biology@gmail.com 
tropical primates that includes Chiropotes and Pithecia as well as Cacajao. Designated by Groves [2001] as a subfamily (Pitheciinae) of the Pitheciidae, the diet of pitheciines is dominated by immature seeds, supplemented with fruit pulp, leaves and flowers [Norconk, 2011]. The great majority of their feeding occurs in the upper forest canopy and emergent trees [Norconk, 2011]. In this group, terrestriality is either very rarely observed (Chiropotes satanas [Veiga, 2006]) or not recorded at all (Chiropotes utahickae [Bobadilla, 1998]; Chiropotes chiropotes [Boyle, 2008]).

The 3 pitheciine genera are broadly separated by habitat [Norconk, 2011]. Pithecia and Chiropotes are generally inhabitants of terra firme forest. Uacaris (genus Cacajao), though exceptions are known (e.g. some populations of C. c. ucayalii and C. c. melanocephalus [Boubli, 1997; Heymann and Aquino, 2010], respectively), principally inhabit forests that are seasonally flooded (C. c. calvus [Ayres, 1986]; Cacajao melanocephalus ouakary [Barnett, 2010]). In these, opportunities for on-the-ground activity are restricted to those few months when floodwaters recede. When recorded [Ayres, 1986], such activities generally involved feeding on the swathes of water-dispersed fruit and fish-dispersed seeds that germinate on the newly exposed forest floor [Parolin, 2001]. In Amazonian flooded forest tree communities, hydrochory and ichthyochory are the dominant dispersal modes; hence, fruit availability occurs in tight pulses that are synchronized across the community [Parolin et al., 2010]. In consequence, there is almost no fruit available in flooded forest tree canopies when forests are unflooded [Barnett, 2010].

While migration to the fruit-bearing canopy of terra firme forest is an option [Haugaasen and Peres, 2005a], exploitation of a superabundant resource is possible in dry igapó if terrestrial foraging options are pursued. However, this is potentially risky as predators such as the tayra (Eira barbara) and jaguar (Panthera onca) enter igapó at this time [Bodmer et al., 1998], probably attracted by the seasonal influx of such seed-predating rodents as the paca (Cuniculus paca) and agouti (Dasyprocta spp.). Thus, terrestrial foraging for uacaris can be potentially highly rewarding, but is also likely to be risky.

While confirmed predation events are generally rare, one likely reason for this is that primates consistently implement strategies to avoid it [Miller, 2002; Hart, 2007]. As has long been appreciated [De Vore and Hall, 1965; Terborgh, 1983; van Schaik et al., 1983], avoiding predation touches nearly all aspects of primate life from foraging, vigilance, cover use and time spent grooming [Hart, 2007], to choice of sleeping trees [Barnett et al., 2012]. Indeed, it may well be one of the major activities structuring the rhythm and form of the primate day [Ferrari, 2009]. Accordingly, much of a primate's foraging activity will be risk sensitive and involve balancing the quality of the available food resource against the possibilities of predation, and likelihood of escaping it [Miller, 2002; Ferrari, 2009]. As C. m. ouakary is essentially an arboreal primate, we would predict therefore that, when foraging terrestrially, golden-backed uacaris will: (i) choose patches with an easy escape route (prediction 1: uacaris will forage close to arboreal escape routes and distant from sites of potential predator concealment); (ii) choose patches with the greatest seed density/total number of seeds (prediction 2: that terrestrially foraging uacaris would also be expected to selectively choose food-dense patches rather than foraging generally on the forest floor; this will involve choosing areas of densely aggregated seedlings over areas where seedlings are sparse, and, when two seed patches are present in an area, uacaris will choose the larger), and (iii) make repeat visits to areas that have previously been safe (prediction 3: once a patch has 
been discovered that meets criteria for safe foraging, it will be exploited repeatedly until the number of seeds is greatly diminished).

We tested these predictions with individuals of C. m. ouakary that were accessing seeds germinating on the floor of seasonally flooded forest (igapó) during the 4 months of the year when the igapó was not fully inundated. During this period the igapó habitat has few alternative food resources for uacaris [Parolin et al., 2010].

\section{Taxonomic Note}

In this paper, the scientific name for Cacajao sp. follows Hershkovitz [1987], since the precise appellation for some members of the genus is currently disputed [Boubli et al., 2008; Ferrari et al., 2009].

\section{Methods}

\section{Study Site}

The study was undertaken in terra firme (non-flooded) and igapó (seasonally flooded) forests [sensu Prance, 1979] at Jaú National Park, a 2,700,000 ha protected area in central Amazonian Brazil. The study was carried out between October 2006 and April 2008 and focused on the area between the first set of major rapids on the Jaú river $\left(01^{\circ} 53^{\prime} 2^{\prime \prime} \mathrm{S}, 61^{\circ} 40^{\prime} 4^{\prime \prime} \mathrm{W}\right)$ and the village of Patauá $\left(01^{\circ} 53^{\prime} 16^{\prime \prime} \mathrm{S}, 61^{\circ} 44^{\prime} 3^{\prime \prime} \mathrm{W}\right)$. Water levels in igapó have strong annual variation: flood waters peak in May-July (up to $15 \mathrm{~m}$ depth), and the forest floor is generally entirely dry only between December and January, and patchily boggy in November and February [Ferreira, 1997]. Data reported here were collected between November and February in 2006, 2007 and 2008. No terrestrial activity was ever observed in terra firme. General study results are reported in Barnett [2010].

\section{Data Collection}

Data on terrestrial feeding were collected as part of a broader study of C. m. ouakary habitat and diet selection [Barnett et al., 2008, 2011, 2012; Barnett, 2010], for which scan sampling was used to quantify diet choice and time budget, and ad libitum sampling was used to collect data on rare or previously unrecorded behaviours. Because terrestrial foraging (a) was not previously recorded for C. m. ouakary and (b) occurred in individual bouts that were always of short duration, all sampling relating to uacari behaviours on the ground were ad libitum. When terrestrial feeding was observed, food debris was searched for immediately after uacaris had ceased feeding. Uacaris were only observed feeding terrestrially at seedling patches (here defined as 'an area made visually distinct, and dimensionally circumscribed, by the enhanced density of seedlings within it') and were not seen to forage across the general forest floor. Accordingly, data were gathered on patch size and seedling density in exploited patches, and their proximity to overhanging boughs and large fallen trunks noted. Feeding sites $(n=7)$ were investigated directly following observation of feeding and the uacaris' subsequent departure.

Germinating seeds were identified by comparison with a photographic database compiled for general studies of C. m. ouakary diet [Barnett, 2010]. Seeds of many igapó tree species are water dispersed (hydrochorous) [Kubitzki and Zibursky, 1994], and tend to accumulate in drifts against floating logs and partly fallen trees. Both the obstacles and their impounded seed rafts slowly descend as the water level drops and the seeds finally contact the ground and germinate. This occurs in concentrated patches, and contrasts greatly with the rest of the forest floor, where undergrowth is almost non-existent and seedling density is low. This makes patches visually very distinct and easily defined. No comparable concentrations of germinating seeds were observed in terra firme.

It is common to use feeding traces to monitor foraging activity when multiple sites are being surveyed simultaneously [Sefczek et al., 2012]. Accordingly, we supplemented observations with data from seeds eaten in our absence. Such indirect sampling was facilitated by direct ob- 
servation of uacaris feeding on germinating seeds, which allowed recognition of other patches where uacaris had been active so that their feeding activity could be easily distinguished from that of other seed-feeding terrestrial mammals (peccaries and rodents). Uacari bite marks lack the distinctive central ridge that characterizes the paired incisor-based gnawing of forest-floor rodents. Rodents normally bite a seed multiple times, uacaris only once. Peccaries ingest seeds whole, and their foraging pattern greatly churns the ground. This contrasts with uacari feeding, where the substrate remains intact and bitten seedlings and plumules are evident.

Though a common and conspicuous feature of the unflooded floor of igapó forest, not all seed patches showed evidence of uacari predation. The hypotheses that this reflected active choice by uacaris and that such choices were driven by predation were tested by comparing the characteristics of 7 seed patches at which feeding had occurred with other patches where it had not. To achieve this, for 2 days immediately following feeding observations we searched for seed patches which lacked feeding signs characteristic of uacaris using an area approximately $500 \times$ $100 \mathrm{~m}$ adjacent to where feeding observations occurred; 17 such sites were found.

To test prediction 1 (easy escape route), distance from patch centre, of both exploited and unexploited patches, to nearest overhanging bough or other arboreal refuge, and distance to the nearest area of dense vegetation were measured $(<4 \mathrm{~m}$ with tape measure, $>4 \mathrm{~m}$ with laser rangefinder; Bushnell Corp., Overland Park, Kans., USA).

Prediction 2 (greatest seed density) was tested in two ways. First, 5 of the 17 sites lacking visual evidence for uacari seed predation were selected and, at these, information on seedling density and species composition were collected (chosen by using the first 5 novel numbers between 1 and 17 to appear in a table of random numbers). Mass and greatest dimension of seeds and proportional mass of seed versus seedling shoot (plumule) were also recorded. Second, we compared in-patch seedling density from the 17 unexploited and 7 exploited patches with the average seedling densities on unflooded igapó floor, using the number of seedlings and their species in 23 randomly placed $1 \mathrm{~m}^{2}$ quadrats in unflooded igapó.

Prediction 3 (repeat visits) was investigated by examining feeding debris. Foraging uacaris ate only the seeds, biting off plumules and leaving them lying on the ground. The resulting wilting patterns were compared with experimentally cut-off plumules to provide a set of reference photos that allowed us to assess whether patches were visited once by uacaris or repeatedly, thus testing prediction 3 (repeat visits). Plumules were categorized as fresh (leaves unwilted or nearly so), wilted (2-3 days since bite: leaves green and supple but lacking luster), very wilted (4-6 days since bite: leaves dry and matt, pale green or grey) and indeterminate (clearly older than 6 days but too broken or dried out for certain classification).

Uacaris did not completely eat all seeds they removed from the seedling patches. Nor did they take to feeding perches some of the seedlings from which they had removed the plumules. To test the effects of partial seed consumption and plumule removal on viability, 25 seedlings from which the plumule had been removed and 25 bitten seeds were removed and replanted in soil collected at the site. Accompanied by 25 unbitten seeds (controls), these were placed in shaded individual plastic containers and watered naturally, when it rained. Survivorship was noted at 30, 60 and 90 days.

To calculate the mean mass of seedlings per square metre, the mean mass for each species was multiplied by the mean overall per square metre, corrected for the mean proportional representation of species present.

\section{Analyses}

Differences between the characteristics of patch types and between randomly placed quadrats and seedling patches were tested using 2-tailed Mann-Whitney U tests (significance level $<0.005$ ). For statistical significance in germination trials, Fisher's exact test (significance level $\mathrm{p}<0.005)$ was used. To test if uacaris were preferentially selecting the seed of one species more than another, Ivlev's index of selectivity was calculated for each species by comparing the mean proportion of seeds eaten at all patches with their proportions in uneaten patches, using the formula:

$$
\mathrm{I}=(\mathrm{U}-\mathrm{A}) /(\mathrm{U}+\mathrm{A})
$$


where $A$ is availability (proportion of total number in sample: eaten plus non-eaten) and $U$ is use (eaten) [Ivlev, 1961]. A '0' Ivlev value indicates the species appears in the diet at the same frequency at which it occurs in the environment (i.e. no active selection). A value above 0 indicates positive selection, a negative value indicates avoidance.

\section{Results}

The material reported here is part of a larger study of C. $m$. ouakary feeding ecology at Jaú National Park [Barnett, 2010]. Overall, Barnett [2010] found only $10.5 \%(1,143$ of 11,902$)$ of feeding records and $11.7 \%$ of the time budget occurred in the lower strata of igapó, including the non-arboreal foraging reported here. The terrestrial feeding reported here represents a small part (7.7\%) of all C. m. ouakary dryseason feeding records, but represents $100 \%$ of such feeding records in unflooded igapó, where no arboreal feeding was recorded, probably because there are no fruits or young leaves for uacari to forage upon at that time. Terrestrial feeding constituted $1.6 \%(190$ of 11,902$)$ of all feeding records, but represents over one third $(37.5 \%)$ of all records of mature seed consumption for C. m. ouakary.

\section{Feeding from Patches of Germinating Seeds - Behavioural Observations}

All terrestrial feeding was observed between December 2007 and January 2008, during the brief period when the igapó forest was unflooded, and its floor was dry. On 6 separate occasions, groups of $2-5$ uacaris $(n=6$, mean $3.7 \pm 1.36 \mathrm{SD})$ were observed feeding on germinating seedlings in open areas on the floor of unflooded igapó, and, at a seventh site, uacaris were disturbed while feeding on the ground, but left before observations could be made. An additional 2 sites were found where field signs (e.g. still moist lacerations on seed testas, plumules cut, but fresh and unwilted) showed feeding had occurred very recently. As uacaris have fission-fusion societies [Bowler and Bodmer, 2009], with groups of 40-100 animals commonly breaking into smaller groups to forage, it is likely that the observed animals were a foraging subgroup.

Uacaris were directly observed to eat 27 germinating seedlings of Eschweilera tenuifolia (Lecythidaceae), and 5 of an undetermined Pouteria species (Sapotaceae). An additional 191 partly eaten seeds were retrieved from patches where uacaris were seen feeding. These included at least 4 tree species (168 E. tenuifolia, 9 Leopoldinia pulchra (Arecaeae), 8 Pouteria sp. and 6 Pouteria elegans). Uacaris were seen to forage only in patches of germinating seeds, and no evidence of their seed feeding (such as bitten seeds or bitten-off plumules) was found away from seed patches, indicating they did not forage elsewhere for seeds on the forest floor. In igapó, seed patches are caused when floating seeds come to rest in rafts against obstructions such as floating branches, and so have a much higher density of seeds than in randomly selected areas of forest floor (see below).

Terrestrially foraging uacaris would eat 3 or 4 seeds from the seedlings at the patch, and then carry in their hands between 1 and 7 additional seedlings to eat at an arboreal refuge. This perch was always 1-4 $\mathrm{m}$ off the ground, with a good view of the surrounding forest floor. No member of a terrestrially foraging group was observed acting as sentinel, but individuals frequently broke off to scan upwards and horizontally. Quadrupedal movement was the most commonly observed, though 
Table 1. Size and density of germinating seedlings at unexploited patches of similar sizes to patches at which feeding had occurred

\begin{tabular}{lllll}
\hline Patch No. & $\begin{array}{l}\text { Patch } \\
\text { size, } \mathrm{m}^{2}\end{array}$ & Seedlings, $\mathrm{n}$ & $\begin{array}{l}\text { Seedlings } \\
\text { (E. tenuifolia/L. pulchra/ } \\
\text { P. elegans/Pouteria } \text { sp.), } \%\end{array}$ & Seedlings $/ \mathrm{m}^{2}$ \\
\hline 1 & 1.8 & 536 & $97.1 / 1.9 / 0.9 / 0.1$ & 297.8 \\
2 & 2.2 & 1,307 & $91.8 / 2.1 / 3.9 / 2.2$ & 594 \\
3 & 2.6 & 743 & $84.5 / 8.1 / 4 / 3.4$ & 285 \\
4 & 3.0 & 1,246 & $80.1 / 11.1 / 5.9 / 2.9$ & 415.3 \\
5 & 3.5 & 1,026 & $98.9 / 0 / 0.4 / 0.7$ & 292.3 \\
Means \pm SD & $2.6 \pm 0.66$ & $971.6 \pm 328.9$ & $90.46( \pm 8.04) / 4.65( \pm 4.72) /$ & $376.8 \pm 132.7$ \\
& & & $3.03( \pm 2.31) / 1.86( \pm 1.4 .1)$ & \\
\hline
\end{tabular}

uacaris heading to a perch would walk 3-limbed and carry seedlings in one hand. Bipedal hopping was also noted.

For all tree seeds eaten, uacaris ate only the seed, with plumules and young leaves being nipped off and discarded. Among the seedlings and plumules showing evidence of uacari seed predation were an additional 11 seedlings ( 3 Eschweilera, 8 Pouteria) with bite marks from rodent teeth. From their size $(4-6 \mathrm{~mm})$ and form, these were caused by Dasyprocta spp. Such seedlings did not have their plumules removed. The relative lack of rodent feeding records in Eschweilera patches was notable, especially as in the same area we recorded 43 incidences of rodent feeding on the cotyledons of Swartzia acuminata (Fabeaceae) seedlings, 13 incidences of their feeding on fungi and 9 of their eating the inflorescences of the root parasite Helosis cayanensis (Balenophoraceae).

The frequency at which Eschweilera seedlings were eaten by C. m. ouakary (88.9\%) was nearly identical to the mean frequency in the 5 seed patches $(90.5 \%$ $\pm 8.04, \mathrm{n}=5$; tables 1,2$)$ where all seedlings $(\mathrm{n}=4,858)$ could be counted and identified (Ivlev value, 0.0089 ). The other species were also eaten in proportions very similar to their abundance (Ivlev values of 0.085, 0.096 and 0.005 for L. pulchra, P. elegans and Pouteria sp., respectively; see table 1 for abundances). Hence, uacaris were not selecting Eschweilera seeds, but taking them in proportion to their absolute abundance.

\section{Seed Germination Experiments}

Of the 25 bitten seeds $100 \%$ had rotted by 90 days, as had 19/25 (76\%) of seeds from which plumules had been removed. The other 6 showed no sign of new plumule production. Twenty (80\%) of 25 unbitten seeds with intact plumules were still growing at 90 days. The difference between germination of damaged $(n=0 / 50)$ versus non-damaged seeds $(n=20 / 25)$ is significant $(p<0.0001$, Fisher's exact test).

\section{Characteristics of Germinating Seeds and Seed Patches}

Of 24 large seedling patches investigated, uacaris fed at only 7. Patches at which feeding occurred were significantly closer to an off-the-ground refuge than those where no evidence of feeding was recorded (Mann-Whitney $U$ test, 2-tailed, $Z=18.5$, 
Table 2. Areas of 7 patches of seedlings exploited by uacaris (patches No. 1-7), compared with 6 unexploited patches within $10 \mathrm{~m}$ of them (patches No. 8-13)

\begin{tabular}{lc}
\hline Patch No. & Patch size, $\mathrm{m}^{2}$ \\
\hline Exploited patches & \\
1 & 1.6 \\
2 & 2 \\
3 & 2.2 \\
4 & 2.4 \\
5 & 2.8 \\
6 & 3 \\
7 & 3.8 \\
Mean \pm SD & $2.54 \pm 0.72$ \\
Unexploited patches & \\
8 & 0.4 \\
9 & 0.6 \\
10 & 0.8 \\
11 & 1 \\
12 & 1.1 \\
13 & 1.6 \\
Mean \pm SD & $0.91 \pm 0.42$ \\
\hline
\end{tabular}

$\mathrm{p}=0.006$; means and SD, $2.6 \pm 1.3$ and $5.7 \pm 2.7 \mathrm{~m}$, respectively). Patches at which feeding occurred were also significantly further away from dense terrestrial vegetation than patches that lacked evidence of feeding (Mann-Whitney U test, 2-tailed, $\mathrm{Z}=17.5, \mathrm{p}=0.0083$; means and $\mathrm{SD}, 18.1 \pm 4.9$ and $12.5 \pm 7.5 \mathrm{~m}$, respectively; table 3 ).

On the igapó forest floor, the mean seedling density in 25 random $1 \mathrm{~m}^{2}$ quadrats was 13.3 (SD \pm 7.5 ; range 5-35; table 4). In contrast, mean seedling density in unexploited patches was $376.8 / \mathrm{m}^{2}$ (SD $\pm 132.7, \mathrm{n}=5$; table 1$)$. Used seedling patches had a mean area of $2.47 \mathrm{~m}^{2}$ ( $\mathrm{SD} \pm 0.77$; table 1 ), while the unused seedling patches used for calculating the density of seedlings and the mass of seedlings per patch had a mean area of $2.6 \mathrm{~m}^{2}(\mathrm{SD} \pm 0.66, \mathrm{n}=5)$. The areas of unvisited patches (table 1) were not significantly different from those at which feeding was observed (Mann-Whitney $\mathrm{U}$ test, 2 -tailed, $\mathrm{Z}=0.405, \mathrm{p}=0.755$ ), indicating that the 5 unvisited patches could be validly used for estimating seedling densities at visited patches. Seedling mass varied between 11.6-24.9 g (mean 16.92, SD 4.87) for E. tenuifolia $(\mathrm{n}=13)$ and between 35.4 and $48.9 \mathrm{~g}$ (mean 41.1, SD 16.14) for $4.9 \mathrm{~g}$ P. elegans $(\mathrm{n}=2)$ with plumules making a small contribution to the overall mass (table 5). The total mass of seeds in a patch varied from 1,750 to $18,718 \mathrm{~g}$ (mean $14,460 \mathrm{~g}$ ). Seedling density at unvisited seedling patches was significantly greater than typical seedling density on the forest floor (mean density of 13.3 seedlings $/ \mathrm{m}^{2}$; table 4; Mann-Whitney $\mathrm{U}$ test, $\mathrm{Z}=-3.462$, $p=0.001$ ), hence the unvisited patches were used as a proxy for the density of the (now-density compromised) visited patches.

Foraging was not recorded in patches that were close to the used patch, but which were $<1 \mathrm{~m}^{2}$. Comparison of size of the visited and ignored patches showed uacaris were only recorded feeding in seed patches $>2 \mathrm{~m}^{2}$. Of the 17 unused patches of $>1 \mathrm{~m}^{2}$ that were studied, 6 were within $10 \mathrm{~m}$ of a visited patch. Patches at which uacaris fed were significantly larger than any of these 6 , neighbouring but unused, patches (Mann-Whitney U test, 2-tailed, $\mathrm{Z}=2.857, \mathrm{p}=0.00427$; table 1). 
Table 3. Distance to nearest arboreal refuge, and to dense terrestrial vegetation for feeding patches (1-7), and large $\left(\geq 1.5 \mathrm{~m}^{2}\right)$ uneaten patches $(\mathrm{A}-\mathrm{Q})$

\begin{tabular}{|c|c|c|}
\hline & $\begin{array}{l}\text { Distance to nearest } \\
\text { arboreal refuge, } \mathrm{m}\end{array}$ & $\begin{array}{l}\text { Distance to nearest dense } \\
\text { terrestrial vegetation, } m\end{array}$ \\
\hline \multicolumn{3}{|l|}{ Feeding patch } \\
\hline 1 & 0.5 & 21.5 \\
\hline 2 & 1.8 & 19.3 \\
\hline 3 & 3.4 & 18.6 \\
\hline 4 & 4.2 & 15 \\
\hline 5 & 3.6 & 17.9 \\
\hline 6 & 2 & 25 \\
\hline 7 & 2.6 & 9.2 \\
\hline Mean $\pm S D$ & $2.6 \pm 1.3$ & $18.1 \pm 5$ \\
\hline \multicolumn{3}{|c|}{ Non-feeding patch } \\
\hline $\mathrm{A}$ & 6 & 15 \\
\hline $\mathrm{B}$ & 2 & 25 \\
\hline $\mathrm{C}$ & 7 & 7 \\
\hline $\mathrm{D}$ & 4.5 & 23 \\
\hline $\mathrm{E}$ & 2.5 & 8 \\
\hline $\mathrm{F}$ & 11 & 10 \\
\hline G & 7 & 21 \\
\hline $\mathrm{H}$ & 8 & 19 \\
\hline I & 8.5 & 6 \\
\hline $\mathrm{J}$ & 6 & 17 \\
\hline $\mathrm{K}$ & 4.5 & 17 \\
\hline $\mathrm{L}$ & 7.5 & 1 \\
\hline M & 3.5 & 15 \\
\hline $\mathrm{N}$ & 5 & 2 \\
\hline $\mathrm{O}$ & 1.5 & 16 \\
\hline $\mathrm{P}$ & 10 & 3 \\
\hline Q & 4 & 7 \\
\hline Mean $\pm S D$ & $5.8 \pm 2.7$ & $12.4 \pm 7.5$ \\
\hline
\end{tabular}

Fresh, wilted and very wilted nipped-off Eschweilera plumules were recovered from the same patch, indicating that patches were being used repeatedly. Comparison of the state of wilt of 100 plumules collected at feeding patches at which uacaris had fed with experimentally manipulated plumules, found fresh plumules (26\%), plumules 2-3 days old (48\%) and 4-6 days old (19\%), with the remainder being indeterminate, as each wilt class suggests some measure of time since last feeding in a patch.

Then we assessed the mean mass of seedlings available per square metre. Excluding the uneaten (and probably toxic [Aparecida de Jesus, 2003; Mergalhães et al., 2003]) seedlings of S. acuminata, the mean percentile proportions of $90.5 \%$ E. tenuifolia, $4.6 \%$ L. pulchra, 3\% P. elegans and 1.9\% Pouteria sp. (table 1) were used. Using the mean value of 377 seedlings $/ \mathrm{m}^{2}$ (table 1), this gives 341 E. tenuifolia, 17 L. pulchra, 11 P. elegans and 7 Pouteria sp. seedlings per square metre. Multiplying by the mean 
Table 4. Density and number of species of germinating seedlings in $1 \mathrm{~m}^{2}$ quadrats on the floor of dry igapó forest

\begin{tabular}{lrrr}
\hline Quadrats & Seedlings $/ \mathrm{m}^{2}$ & Species, $\mathrm{n}$ & E. tenuifolia, $\%$ \\
\hline 1 & 9 & 3 & 0 \\
2 & 5 & 2 & 0 \\
3 & 21 & 2 & 33.0 \\
4 & 23 & 3 & 56.5 \\
5 & 24 & 3 & 75.0 \\
6 & 8 & 2 & 50.0 \\
7 & 14 & 2 & 92.8 \\
8 & 12 & 2 & 91.7 \\
9 & 12 & 3 & 25.0 \\
10 & 7 & 2 & 0 \\
11 & 6 & 2 & 33.0 \\
12 & 25 & 2 & 80.0 \\
13 & 15 & 2 & 73.3 \\
14 & 9 & 3 & 11.1 \\
15 & 10 & 2 & 40.0 \\
16 & 10 & 3 & 70.0 \\
17 & 9 & 3 & 44.4 \\
18 & 9 & 2 & 66.6 \\
19 & 9 & 2 & 33.3 \\
20 & 6 & 4 & 16.7 \\
21 & 15 & 3 & 13.3 \\
22 & 12 & 4 & 8.3 \\
23 & 35 & 31.4 & 41.1 \\
Mean & SD & 3.6 & \\
\hline
\end{tabular}

Table 5. Mean size and mass of germinating seedlings encountered in patches

\begin{tabular}{lcccc}
\hline Species & $\mathrm{n}$ & $\begin{array}{l}\text { Mean length } \pm \mathrm{SD} \\
\mathrm{mm}\end{array}$ & $\begin{array}{l}\text { Mean mass } \pm \mathrm{SD} \\
\mathrm{g}\end{array}$ & $\begin{array}{l}\text { Percent mass } \\
\text { plumule }\end{array}$ \\
\hline E. tenuifolia & 13 & $60.03 \pm 8.06$ & $16.92 \pm 4.87$ & $1.5 \pm 0.37$ \\
L. pulchra & 10 & $21.16 \pm 1.68$ & $21.84 \pm 3.42$ & $3.57 \pm 0.57$ \\
P. elegans & 20 & $42.1 \pm 7.05$ & $41.15 \pm 16.14$ & $2.4 \pm 0.8$ \\
Pouteria sp. & 7 & $38.6 \pm 6.5$ & $32.6 \pm 15.7$ & $2.7 \pm 0.8$ \\
S. acuminata & 20 & $135.6 \pm 26.72$ & $239.5 \pm 93.03$ & $4.43 \pm 1.23$ \\
\hline
\end{tabular}

masses for these seeds (table 5) gives 5,769.7 $\mathrm{g}$ of E. tenuifolia, $371.3 \mathrm{~g}$ of L. pulchra, $452.7 \mathrm{~g}$ of $P$. elegans and $228.2 \mathrm{~g}$ of Pouteria sp. seedlings per square metre. This gives a total of $6,821.2 \mathrm{~g}$ of edible seedlings per square metre. Exploited seedling patches had a mean size of $2.54 \mathrm{~m}^{2}$, indicating a mass of 17,325.8 $\mathrm{g}$ of edible seedlings per mean patch. 


\section{Discussion}

Our data supported prediction 1 (easy escape route), prediction 2 (greatest seed density/numbers) and prediction 3 (repeated visits). The study has shown seed patches at which C. m. ouakary fed were close to a refuge, were larger than those where no feeding was recorded and had high seedling densities. It appears highly likely that these patches were visited regularly. C. m. ouakary leaves a characteristic feeding signature, which is unlike that of either rodents or peccaries in the region. The differential stages of wilting observed in the discarded plant remains indicates repeat visits. This is interpreted as implying predator-sensitive foraging. Comparing this with actions by other Cacajao sp. is compromised by the lack of similar studies. Although white bald uacaris (C. c. calvus) were recorded foraging terrestrially for germinating seeds by Ayres [1986], associated foraging behaviour was not recorded and no information was provided on the dispersion of the seedlings. At Ayres' [1986] study site there was little terrestrial mammalian activity when the flooded forest was dry which led Ayres [1993] to suggest that terrestrial feeding occurred on the floor of unflooded várzea forest, primarily because it was a low-risk foraging strategy (see also Lopes and Ferrari [1994]). This was an appropriate explanation for várzea, where large predators are generally rare or absent from these broad flood plains [Bodmer et al., 1998; Haugaasen and Peres, 2005b], but is unlikely to be valid for the narrow ribbon-like igapó, as it is immediately adjacent to terra firme and is visited in the dry season by jaguar and other terra firme-based predators [Bodmer et al., 1998; Haugaasen and Peres, 2005b; Barnett, unpubl. data].

The study has shown that uacaris prefer large seed patches, distant from dense terrestrial vegetation and close to a source of arboreal refuge where most seeds were then eaten. We consider it plausible that uacaris are basing their decisions about where to forage on both density and quantity of germinating seeds and the risk involved in obtaining them. In addition, since the density of seeds in the grounded seed rafts far exceeded the density in other parts of the forest floor, we believe that uacaris also choose to feed on the most abundant terrestrial seed resource, the biomass of which is considerable. Whether uacaris cease to visit patches once seed densities fall below certain levels was not investigated in the current study, but is clearly an avenue for future research.

In the absence of information on relative predation rates on uacaris foraging at patches of different types, the interpretation that avoidance of seed patches near dense vegetation functions to reduce the possibility of predation is, of course, supposition. But, as Ferrari [2009] has pointed out, predation on primates may be rare precisely because of the predator avoidance strategies the animals employ. Such a strategy is, we believe, the most parsimonious interpretation of the available data. Terrestrially hunting predators known to take Neotropical primates include jaguar (P. onca) [Peetz et al., 1992; Olmos, 1994] and cougar (P. concolor) [Novack et al., 2005] preying on adults, and smaller felids preying on juveniles and infants [e.g. jaguarundi, Puma yagouaroundi [Tófoli et al., 2009]; ocelot, Leopardus pardalis [Miranda et al., 2005; Bianchi and Mendes, 2007]). For the jaguar, ambush from dense vegetation is the most frequent hunting strategy [Seymour, 1989; Rosa and Nocke, 2000]. Foraging in várzea may be low risk because the floodplains on which they grow are extensive and consist of long, narrow, largely parallel levees; 
consequently, connectivity to the predator-rich terra firme is low. In igapó, although foraging terrestrially may reduce the risk from aerial predators such as harpy eagles [Barnett et al., 2011], it is not a risk-free enterprise. Though most Amazonian mammals can swim [Goulding, 1990], floodwater seasonally prevents terrestrial mammals from foraging in igapó except for the 2-3 months when the waters recede and the forest floor is exposed. This period is one of intense germination activity [Parolin, 2001], and rodents, deer, tapir and peccary all enter into igapó to feed on this bonanza [Bodmer et al., 1998; Haugaasen and Peres, 2005a, b]. Predators, like jaguar and smaller cats, enter to feed on the herbivores [Seymour, 1989; Haugaasen and Peres, 2005b], as well as nesting river turtles and their eggs [Salera Jr. et al., 2009] and caiman eggs [Villamarín-Jurado and Suárez, 2009; Silveira et al., 2010].

With mean edible seedling mass per patch exceeding $17 \mathrm{~kg}$, grounded seed rafts clearly represent a potentially important food resource for C. m. ouakary. However, in addition to abundance, food quality may also be an important factor in food choice. As seeds mature, their water content tends to decline, while the carbohydrate, fat and protein content proportionately increases [Laboriau, 1983]. Terrestrial foraging has not been reported for C. m. melanocephalus in Pico da Neblina, Brazil [Boubli, 1997], nor for C. c. ucayalii at Lago Preto, Peru [Bowler, 2007]. In both areas fruit is present year-round in the canopy, and this may well negate the need to descend to the ground to feed. This is not the case at Jaú, where the igapó forest has a marked seasonal fruit dearth [Barnett, 2010], such that there is little or no fruit or young leaves on which a uacari could forage.

We have shown that uacaris both remove seedlings and eat them and also that seeds bitten and then dropped seldom survive. This, and the fact that uacaris appear to repeatedly visit certain patches, means that they could be acting as sources of considerable seedling mortality within them. However, because the animals appear to be choosing patches where density is high, and also appear to prefer seeds that are just launching their plumules, it is considered very likely that uacaris will move to a second patch once the seedlings in the first become too old and sparse. Under such circumstances it is likely that these primates will, in fact, be acting as substantial thinning agents on the population of developing Eschweilera seedlings. Given the widely established effects of excessive crowding on seedling development and survivorship [Pacala and Silander, 1985, 1990; White, 1986], it is possible that uacaris are enhancing the survivorship possibilities of these seedlings which escape their attention. This possibility has also been mooted by Lopes and Ferrari [1994] for C. c. calvus and Eschweilera albiflora, though again the quantitative data to test it are lacking. However, similar effects have been recorded in other systems involving plants and mammalian seed predators. For example enhanced seedling mortality among Berteroa incana (Brassicaceae) plants in areas burrowed by pocket gophers (Geomys bursarius) also results in greater growth and survivorship among the non-predated seedlings [Reichmann, 1988].

Uacaris are not alone in foraging for seeds on the floor of igapó. Rodents, such as Cuniculus, Dasyprocta and Proechimys sp. are all known to enter and forage on seeds, though their foraging ecology in igapó is, to date, unstudied. From the very preliminary data, they appear to be slight competitors within the superabundant resource that each seed patch represents. In addition, we would argue that the foraging actions of the rodents themselves are of little or no functional importance to a forag- 
ing uacari, which appears to be basing its decision to use a patch on the apparent size and density of the patch - and its proximity to escape routes and to potential predator-concealing cover - irrespective of the means by which such densities have been arrived at.

\section{Acknowledgments}

Fieldwork was undertaken with CNPq-IBAMA Protected Area Study License 138/2006. IBAMA-Manaus issued monthly park research permits. Funding was generously provided by the American Society of Primatologists, Columbus Zoo Conservation Fund, Sophie Danforth Conservation Fund, LSB Leakey Foundation (USA), Leakey Fund (UK), Laurie Shapley, Margot Marsh Foundation, Oregon Zoo Conservation Fund, Percy Sladen Memorial Fund, Pittsburgh Zoo and Aquarium Conservation Fund, Primate Action Fund, Primate Conservation Inc., Roehampton University and Wildlife Conservation Society. Technical assistance was provided by the Fundação Vitória Amazônica. A.A.B., T.A. and W.S.S. also thank Eliana dos Santos Andrade, Eduardo do Souza, Maria de Bom Jesus, Roberto Morreira and the IBAMA staff at Jaú. The manuscript was written while A.A.B. was a visiting scientist at the Instituto National de Pesquisas de Amazônia (under PCI-INPA initiative and CNPq Bolsa de Curta Duracao, BEV, grant, No. 680.004/2009-2). We thank three anonymous reviewers for their comments and suggestions and also the journal's editorial staff. This is contribution 12 of the Igapó Study Project.

\section{References}

Aparecida de Jesus M (2003). Efeitos dos estratos obtidos de Swartzia argentata Spruce ex. Benth, S. laevicarpa Amshoff, S. pancoco (Aublet) Cowan, S. polyphylla DC e de S. serica Vogel da Amazônia central sobre fongos degradores da madeira. $\mathrm{PhD}$ dissertation, University of São Paulo, Rio Claro.

Ayres JM (1986). Uakaris and Amazonian Flooded Forest. PhD dissertation, University of Cambridge.

Ayres JM (1993). As Matas de Várzea do Mamirauá. Tefé, Sociedade Civil Mamirauá.

Barnett AA (2010). Diet, Habitat Use and Conservation Ecology of the Golden-Backed Uacari, Cacajao melanocephalus ouakary, in Jaú National Park, Amazonian Brazil. PhD dissertation, Roehampton University, London. http://roehampton.openrepository.com/roehampton/.

Barnett AA, Bezerra B, Ross C, MacLarnon A (2008). Hard fruits and black waters: the conservation ecology of the golden-backed uacari, Cacajao melanocephalus ouakary, an extreme diet- and habitat-specialist. Presentation No 692, abstracts. XXIIth Congress of the International Primatological Society, Edinburgh, August 2-8, pp 248-250.

- Barnett AA, Schiel V, Deveny A, Valsko J, Spironello WR, Ross C (2011). Predation on Cacajao ouakary and Cebus albifrons (Primates: Platyrrhini) by harpy eagles. Mammalia 75: 169-172.

Barnett AA, Shaw P, MacLarnon A, Ross C (2012). Sleeping site selection by golden-backed uacaris, Cacajao melanocephalus ouakary (Pithecidae), in Amazonian flooded forests. Primates DOI: 10.1007/s10329-012-0296-4.

- Bianchi RC, Mendes SL (2007). Ocelot (Leopardus pardalis) predation on primates in Caratinga Biological Station, Southeast Brazil. American Journal of Primatology 69: 1-6.

Bobadilla UL (1998). Abundância, tamanho de agrupamento e uso de habitat por cuxiús de Uta Hick, Chiropotes satanás utahicki Hershkovitz, 1985 em dois sítios na Amazônia oriental. MSc dissertation, Universidade Federal do Pará, Belém.

Bodmer RE, Puertas PE, Garcia JE, Diaz R (1998). Game animals, palms and people of the flooded forest: management considerations for the Pacaya-Samiria National Reserve, Peru. Advances in Economic Botany 13: 217-232.

Boubli J-P (1997). Ecology of the Black Uakari Monkey, Cacajao melanocephalus melanocephalus, in Pico da Neblina National Park, Brazil. PhD dissertation, University of California, Berkeley.

Boubli JP, da Silva MNF, Amado MV, Hrbek T, Pontual FB, Farias IP (2008). A taxonomic reassessment of Cacajao melanocephalus Humboldt (1811), with the description of two new species. International Journal of Primatology 29: 723-741. 
Bowler M (2007). The Ecology and Conservation of the Red Uakari Monkey on the Yavari River, Peru. $\mathrm{PhD}$ dissertation, University of Kent, Canterbury.

Bowler M, Bodmer R (2009). Social behavior in fission-fusion groups of red uakari monkeys (Cacajao calvus ucayalii). American Journal of Primatology 71: 976-987.

Boyle SA (2008). The Effects of Forest Fragmentation on Primates in the Brazilian Amazon. PhD dissertation, Arizona State University, Tempe.

Campbell CJ, Aurelli F, Chapman CA, Ramos-Fernandez G, Matthews K, Russo SE Suarez S, Vick L (2005). Terrestrial behavior of Ateles spp. International Journal of Primatology 26: 1039-1051.

De la Rosa CL, Nocke C (2000). A Guide to the Carnivores of Central America: Natural History, Ecology, and Conservation. Austin, University of Texas Press.

De Vore I, Hall KRL (1965). Baboon ecology. In Primate Behavior: Field Studies of Monkeys and Apes (De Vore I, ed.), vol I, pp 20-52. New York, Holt Rinehart \& Winston.

Ferrari SF (2009). Predation risk and antipredator strategies. In South American Primates: Comparative Perspectives in the Study of Behavior, Ecology and Conservation (Garber PA, Estrada A, BiccaMarques JC, Heymann EW, Strier KB, eds.), pp 251-278. New York, Springer Academic Press.

Ferrari SF, Barnett AA, Figueiredo de WMB, Guedes P (2009). Uma reconsideração da nomenclatura dos uacaris de cara-preta (grupo Cacajao melanocephalus, sensu Hershkovitz, 1987) ao norte da bacia Amazônica. Abstracts on CD-ROM. XIIIth Brazilian Primatology Congress, Blumenau.

Ferreira LV (1997). Effects of the duration of flooding on species richness and floristic composition in three hectares in the Jaú National Park in floodplain forests in central Amazonia. Biodiversity and Conservation 6: 1353-1363.

Groves C (2001). Primate Taxonomy. Washington, Smithsonian Institute Press.

Goulding M (1990). Amazon: The Flooded Forest. London, Stirling Publishing Co.

Hart D (2007). Predation on primates: a biogeographical analysis. In Primate Anti-Predator Strategies (Gursky SL, Nekaris KAI eds.), pp 27-59. New York, Springer.

Haugaasen T, Peres CA (2005a). Tree phenology in adjacent Amazonian flooded and unflooded forests. Biotropica 37: 620-630.

Haugaasen T, Peres CA (2005b). Mammal assemblage structure in Amazonian flooded and unflooded forests. Journal of Tropical Ecology 21: 133-145.

Heymann E, Aquino E (2010). Peruvian red uakaris (Cacajao calvus ucayalii) are not flooded-forest specialists. International Journal of Primatology 31: 751-758.

Ivlev VS (1961). Experimental Ecology of the Feeding of Fishes. New Haven, Yale University Press.

Kubitzki K, Zibursky A (1994). Seed dispersal in flood plain forests of Amazonia. Biotropica 26: 30-43.

Laboriau IG (1983). A Germinação das Sementes. Biology series, monograph No 29. Washington, OEAPRDCT.

Lopes MA, Ferrari SF (1994). Differential recruitment of Eschweilera albiflora (Lecythidaceae) seedlings at two sites in western Brazilian Amazonia. Tropical Ecology 35: 25-34.

Miller LE (2002). An introduction to predator sensitive foraging. In Eat or Be Eaten: Risk Sensitive Foraging among Primates (Miller LE, ed.), pp 1-17. Cambridge, Cambridge University Press.

Miranda JMD, Bernardi IP, Abreu KC, Passos FC (2005). Predation on Alouatta guariba clamitans Cabrera (Primates, Atelidae) by Leopardus pardalis (Linnaeus) (Carnivora, Felidae). Revista Brasiliera de Zoologia 22: 793-795.

Norconk MA (2011). Sakis, uakaris, and titi monkeys: behavioral diversity in a radiation of primate seed predators. In Primates in Perspective (Campbell CJ, Fuentes A, MacKinnon KC, Bearder SK, Stumpf RM, eds.), pp 122-139. New York, Oxford University Press.

Novack AJ, Main MB, Sunquist ME, Labisky RF (2005). Foraging ecology of jaguar (Panthera onca) and puma (Puma concolor) in hunted and non-hunted sites within the Maya Biosphere Reserve, Guatemala. Journal of Zoology (London) 267: 167-178.

- Nowak K, Lee P (2011). Demographic structure of Zanzibar red colobus populations in unprotected coral rag and mangrove forests. International Journal of Primatology 32: 22-45.

Olmos F (1994). Jaguar predation on muriqui, Brachyteles arachnoides. Neotropical Primates 2: 16.

Pacala SW, Silander JA (1985). Neighborhood models of plant population dynamics. I. Single species models of annuals. American Naturalist 125: 385-341.

Pacala SW, Silander JA (1990). Field tests of neighborhood population dynamics models for two weed species. Ecological Monographs 50: 113-134.

Parolin P (2001).Seed germination and early establishment in 12 tree species from nutrient-rich and nutrient-poor Central Amazonian floodplains. Aquatic Botany 70: 89-103.

Parolin P, Wittmann F, Schöngart J (2010). Tree phenology of Amazonian floodplain forests. In Amazonian Floodplain Forests (Junk W et al, eds.), pp 105-126. New York, Springer.

Peetz A, Norconk MA, Kinzey WG (1992). Predation by jaguar on howler monkeys (Alouatta seniculus) in Venezuela. American Journal of Primatology 28: 223-228.

Prance GT (1979). Notes on the vegetation types of Amazonia. III. The terminology of Amazonian forest types subject to inundation. Brittonia 31 : 26-38. 
Reichman OJ (1988). Comparison of the effects of crowding and pocket gopher disturbance on mortality, growth and seed production of Berteroa incana. American Midland Naturalist 120: 58-69.

- Salera G Jr, Portelinha TCG, Malvasio A (2009). Predação de fêmeas adultas de Podocnemis expansa Schweigger (Testudines, Podocnemididae) por Panthera onca Linnaeus (Carnivora, Felidae), no Estado do Tocantins. Biota Neotropica 9: 387-391.

Seymour KL (1989). Panthera onca. Mammalian Species 340: 1-9.

- Sefczek TM, Farris ZJ, Wright PC (2012). Aye-Aye (Daubentonia madagascariensis) feeding strategies at Ranomafana National Park, Madagascar: an indirect sampling method. Folia Primatolica 83: $1-10$.

-Silvira R, Ramalho EE, Thorbjarnarson JB, Magnusson WE (2010). Depredation by jaguars on caimans and importance of reptiles in the diet of jaguar. Journal of Herpetology 44: 418-424.

Smith L, Link A, Cords M (2008). Cheek pouch use, predation risk and feeding competition in blue monkeys (Cercopithecus mitis stuhlmanni). American Journal of Physical Anthropology 137: 334341.

Tabacow FP, Mendes SL, Strier KB (2009). Spread of a terrestrial tradition in an arboreal primate. American Anthropologist 111: 238-249.

Terborgh J (1983). Five New World Primates: A Study in Comparative Ecology. Princeton, Princeton University Press.

Van Schaik CP, van Noordwijk MA, Warsono B, Sutriono E (1983). Party size and early detection of predators in Sumatran forest primates. Primates 24: 211-221.

Veiga LM (2006). Ecologia e comportamento do cuxiú-preto (Chiropotes satanas) na paisagem fragmentada da Amazônia Oriental. $\mathrm{PhD}$ dissertation, Universidade Federal do Pará, Belém.

-Villamarín-Jurado F, Suárez E (2009). Nesting of the black caiman (Melanosuchus niger) in northeastern Ecuador. Journal of Herpetology 41: 164-167.

White J (ed.) (1986). Studies on Plant Demography: A Festschrift for John L. Harper. London, London Academic Press. 